\title{
FAKTOR-FAKTOR YANG MENENTUKAN KEBIMBANGAN KARIER PADA SISWA SMA KELAS XII
}

\author{
Sari Zakiah Akmal \\ Fakultas Psikologi Universitas YARSI \\ Jl. Letjend Suprapto Kav.13, Menara YARSI Lt. 6, Cempaka Putih, Jakarta \\ sari.zakiah@gmail.com
}

\begin{abstract}
Career decision is one of the major issue among XII grade of high school students, particularly choosing major in university. Most of high school students experience career indecision. There are some factors that predict career indecision problems among adolescents. This study aims to identify factors that significantly affect career indecision among high school students, particularly personality and career decision making self-efficacy factors. This study used quantitative method and data were collected using Indonesian version of Big Five Inventory, Career Decision Making Self-Efficacy Scale, and Career Decision Scale. We recruited 259 participants using incidental sampling $(65.3 \%$ female, $M$ age $=16.67$ years, $S D=.62)$. Hierarchical regression analysis demonstrated that personality factors, particularly openness to experiences and neuroticism predicted career indecision among high school students. Neuroticism was associated positively and openness to experiences was correlated negatively with career indecision. Meanwhile, career decision making self-efficacy was not correlated with career indecision. Therefore, practitioner should design an intervention to overcome student's career indecision problem by reducing anxiety, decreasing fear in career decision making and encouraging students to looking for more information about their interest and career path.
\end{abstract}

Keywords: career indecision; personality; career decision making self-efficacy; high school students

\begin{abstract}
Abstrak
Pemilihan jurusan di perguruan tinggi menjadi salah satu isu penting bagi siswa kelas XII. Bagi sebagian siswa, pemilihan jurusan dan penentuan karier yang akan dijalani bukanlah hal mudah, terlihat dari banyaknya siswa yang merasa bingung ketika ingin memilih jurusan di perguruan tinggi. Terdapat beberapa faktor yang diperkirakan berperan terhadap pengambilan keputusan karier siswa. Penelitian ini dilakukan untuk mengidentifikasi faktor-faktor yang berperan terhadap kebimbangan karier siswa. Penelitian ini membahas peran faktor kepribadian dan keyakinan dalam pengambilan keputusan karier. Penelitian ini dilakukan dengan menggunakan pendekatan kuantitatif. Data diperoleh dengan menggunakan Big Five Inventory, Career Decision Making Self-Efficacy Scale, dan Career Decision Scale yang sudah diadaptasi ke dalam Bahasa Indonesia. Penelitian ini melibatkan 259 siswa SMA Kelas XII di Jadebotabek (65,3\% perempuan, rata-rata usia 16,76 tahun, $S D=0,62$ ) yang direkrut dengan menggunakan teknik incidental sampling. Data hasil penelitian dianalisis dengan menggunakan uji regresi bertingkat (hierarchical regression). Hasil penelitian menunjukkan bahwa faktor kepribadian, lebih berperan terhadap kebimbangan karier pada siswa SMA Kelas XII. Faktor kepribadian neuroticism berkorelasi positif dengan kebimbangan karier, sedangan kepribadian openness to experiences berkorelasi negatif dengan kebimbangan karier. Sementara itu, keyakinan dalam pengambilan keputusan karier tidak menjadi faktor yang memprediksi kebimbangan karier siswa SMA kelas XII. Oleh karena itu, intervensi yang dapat diberikan untuk mengatasi masalah kebimbangan karier siswa adalah dengan mengurangi kecemasan dan ketakutan dalam pengambilan keputusan karier dan mendorong siswa untuk lebih mencari tahu informasi mengenai karier yang ingin ditekuninya.
\end{abstract}

Kata kunci: kebimbangan karier; kepribadian; keyakinan dalam pengambilan keputusan karier; siswa SMA

\section{PENDAHULUAN}

Siswa SMA kelas XII berada pada masa transisi dari pendidikan menengah ke pendidikan tinggi, mereka sudah harus memikirkan salah satu langkah penting dalam perencanaan kariernya yaitu pemilihan jurusan. Pemilihan jurusan merupakan hal penting yang perlu dipertimbangkan remaja dengan baik karena mementukan jurusan 
yang akan ditekuni merupakan perpaduan antara keinginan, harapan, dan pandangan remaja terkait dengan masa depan (Talib \& Tan, 2009). Meskipun sudah menjadi salah satu tugas perkembangan yang harus diselesaikan oleh remaja, ternyata perencanaan karier dan pengambilan keputusan karier bukanlah hal mudah yang dapat dilakukan oleh remaja.

Beberapa penelitian memperkirakan bahwa $50 \%$ siswa yang terlibat dalam penelitian mengenai pengambilan keputusan karier, menunjukkan bahwa mereka mengalami masalah kebimbangan karier (Gianakos dalam Creed, Patton, \& Prideaux, 2006). Persoalan kembimbangan karier muncul karena banyaknya pilihan jurusan dan pekerjaan yang tersedia, adanya pertimbangan untuk menyesuaikan dengan kebutuhan dan nilai yang dianut individu dan adanya pertentangan antara beberapa faktor yang menjadi pertimbangan dalam pengambilan keputusan (Creed dkk., 2006).

Permasalahan yang serupa terkait pengambilan keputusan karier juga ditemui di Indonesia. Berdasarkan hasil survei yang dilakukan oleh Inisiator Semua Murid Semua Guru (SMSG) yang dimuat dalam media massa daring di Indonesia menunjukkan bahwa ketika sudah berada di bangku perguruan tinggi pun, mahasiswa di Indonesia masih mengalami permasalahan terkait pengambilan keputusan karier. Hasil survei menunjukkan bahwa $90 \%$ mahasiswa di Indonesia mengalami kebimbangan karier saat memilih jurusan kuliah dan $87 \%$ mahasiswa merasa salah dalam memilih jurusan (Napitupulu, 2018). Oleh karena itu, masalah kebimbangan karier ini menjadi hal yang penting dibahas karena pengambilan keputusan karier bisa berdampak jangka panjang. Penetapan jurusan dapat mengikat siswa ke jalur karier tertentu yang dapat melibatkan pendidikan dan pelatihan dalam jangka panjang sebelum meraka benar-benar terjun ke pekerjaannya (Creed dkk., 2006). Kesalahan dalam memilih jurusan di perguruan tinggi bisa membuat individu tidak menyukai bidang studi yang terlanjur dipilih serta tidak bisa mengikutinya, tidak merasa bahagia, sulit bergaul, bahkan bisa drop out.

Penelitian mengenai kebimbangan karier sudah banyak dilakukan sebelumnya oleh peneliti di negara-negara Barat. Kebimbangan karier berkaitan dengan faktor individu, seperti usia dan jenis kelamin (Creed \& Patton, 2001), berkorelasi negatif dengan berbagai variabel yang terkait dengan perkembangan karier, seperti kematangan karier, keyakinan diri, pengetahuan terhadap pekerjaan dan dukungan sosial (Creed dkk., 2006). Selain itu, kebimbangan karier juga berkorelasi dengan beberapa variabel interpersonal seperti ketakutan akan keberhasilan, penilaian diri yang rendah, kurangnya kesadaran diri, kecemasan dan keterampilan sosial yang rendah (Creed dkk., 2006). Selain faktor-faktor tersebut, faktor kepribadian juga berperan signifikan dalam proses pengambilan keputusan karier individu, terlihat dari banyaknya penelitian terdahulu yang sering mengaitkan variabel kepribadian dengan pengambilan keputusan karier.

Menurut Lounsbury, Hutchens, dan Loveland (2005), terdapat beberapa alasan yang menekankan pentingnya mengetahui peranan kepribadian terhadap kebimbangan karier siswa. Pertama, dengan mengetahui aspek kepribadian yang paling berperan dalam pengambilan keputusan karier maka akan dapat memberikan penjelasan teoritis tentang proses pengambilan keputusan karier. Kedua, keterkaitan antara kedua variabel tersebut dapat membantu praktisi dalam mengembangkan dan mengevaluasi program intervensi yang telah dilakukan. Meskipun penelitian mengenai kepribadian dan kebimbangan karier sudah banyak dilakukan oleh penelitian sebelumnya di negara-negara Barat, penelitian ini masih perlu dikembangkan untuk populasi siswa SMA kelas XII di Indonesia, karena perbedaan budaya diasumsikan menjadi 
salah satu faktor yang menyebabkan adanya perbedaan karakteristik kepribadian individu. Salah satu teori yang umum digunakan untuk menjelaskan tentang trait kepribadian adalah big five personality. Dalam teori tersebut, diyakini bahwa terdapat lima faktor utama dalam kepribadian seseorang yang terdiri atas openness to experiences, conscientiousness, extraversion, agreeableness, dan neuroticisim. Terkait dengan proses pengambilan keputusan karier, ditemukan dua faktor kepribadian yang cukup konsisten berkaitan dengan kebimbangan karier yaitu neuroticis dan conscientiousness (Martincin \& Stead, 2015), sementara itu faktor kepribadian lainnya cenderung tidak menunjukkan adanya hubungan yang signifikan dengan pengambilan keputusan karier. Individu dengan faktor kepribadian neuroticism yang dominan, diperkirakan akan cenderung mengalami kebimbangan karier karena mereka memiliki kecemasan yang tinggi, mudah mengalami stres, dan cenderung memiliki ide yang kurang realistis (Lounsbury dkk., 2005; Ramdhani, 2012). Sementara itu, individu dengan faktor kepribadian conscientiousness yang dominan, cenderung akan lebih yakin dalam mengambil keputusan kariernya karena mereka dapat mengetahui keinginannya, fokus pada tujuan, bertanggung jawab dan berorientasi pada prestasi sehingga diperkirakan mereka akan lebih terarah dalam memilih kariernya (Lounsbury dkk., 2005; Ramdhani, 2012).

Selain faktor kepribadian, faktor personal lainnya yang juga berkaitan dengan kebimbangan karier adalah keyakinan dalam pengambilan keputusan karier. Keyakinan dalam pengambilan keputusan karier menggambarkan penilaian seseorang mengenai kemampuannya dalam menyelesaikan tugas-tugas yang terkait dengan proses pengambilan keputusan karier seperti penilaian diri, mencari informasi karier, membuat perencanaan, menetapkan pilihan, dan menyelesaikan persoalan terkait karier (Betz \& Hackett, 2006; Creed dkk., 2006). Arlinkasari, Rahmatika, dan Akmal (2016) melakukan penelitian mengenai konstruk ini pada populasi dewasa muda di Indonesia dan menambahkan dimensi afirmasi sosial sebagai salah satu unsur penting dalam pengambilan keputusan karier. Dimensi ini membahas tentang keyakinan individu untuk mendapatkan dukungan dari lingkungan sosialnya terkait dengan keputusan karier yang akan diambil (Arlinkasari dkk., 2016).

Penelitian yang mengaitkan antara kebimbangan karier dengan keyakinan dalam pengambilan keputusan karier juga sudah umum dilakukan (Creed dkk., 2006). Akan tetapi, masih ditemukan hasil yang belum konsisten mengenai keterkaitan antara kedua variabel tersebut. Penelitian yang dilakukan oleh Guay, Senécal, Gauthier, dan Fernet (2003) menunjukkan bahwa keyakinan dalam pengambilan keputusan karier merupakan prediktor kuat dalam menentukan kebimbangan karier individu. Semakin yakin seseorang dengan kemampuannya dalam mengambil keputusan karier makan akan semakin kecil kemungkinannya mengalami kebimbangan karier. Sementara itu, penelitian yang dilakukan oleh Creed dkk. (2006) menunjukkan bahwa keyakinan dalam pengambilan keputusan karier bukan merupakan prediktor dari kebimbangan karier individu. Oleh karena itu, penelitian ini dilakukan kembali untuk melihat bagiamana keterkaitan antara keyakinan dalam pengambilan keputusan karier dengan kebimbangan karier pada populasi siswa SMA kelas XII di Indonesia.

Berdasarkan pemaparan di atas diketahui bahwa permasalahan kebimbangan karier pada siswa SMA kelas XII merupakan salah satu isu penting yang perlu diatasi. Beberapa penelitian di negara Barat menunjukkan bahwa faktor kepribadian mempengaruhi kebimbangan karier individu, namun belum ditemukan hasil yang konsisten mengenai faktor kepribadian yang dominan berperan dalam memprediksi kebimbangan karier. Selain itu, penelitian sebelumnya masih menunjukkan hasil yang belum konsisten mengenai peran keyakinan dalam 
pengambilan keputusan karier terhadap kebimbangan karier. Oleh karen itu, penelitian ini perlu dilakukan untuk meninjau kembali bagaimana peranan kedua variabel tersebut terhadap kebimbangan karier siswa SMA kelas XII. Hipotesis dari penelitian ini adalah karakteristik kepribadian neuroticism, conscitiousness dan keyakinan dalam pengambilan keputusan karier akan berperan dalam menentukan kebimbangan karier pada siswa SMA kelas XII.

\section{METODE}

Penelitian ini menggunakan pendekatan penelitian kuantitatif untuk menguji hipotesis mengenai keterkaitan antara variabel kepribadian, keyakinan dalam pengambilan keputusan karier dan kebimbangan karier pada siswa SMA kelas XII. Populasi penelitian ini adalah siswa SMA kelas XII yang bersekolah di wilayah Jadebotabek. Penelitian ini fokus melihat masalah kebimbangan karier pada siswa SMA kelas XII karena pengambilan keputusan karier terutama pemilihan jurusan dan pekerjaan merupakan salah satu permasalahan umum bagi siswa. Berdasarkan data dari Kementrian Pendidikan dan Kebudayaan (2017) diketahui bahwa populasi siswa SMA kelas XII di Jakarta berjumlah 50.569. Peneliti menggunakan acuan dari tabel Isaac dan Michael (dalam Sugiyono, 2010) untuk menentukan jumlah sampel penelitian. Berdasarkan tabel Isaac dan Michael (dalam Sugiyono, 2010), jumlah sampel yang dibutuhkan untuk populasi 50.000 dengan derajat error 5\% adalah 346 sampel.

Partisipan penelitian direkrut dengan menggunakan teknik incidental sampling. Pengumpulan data dilakukan dengan pemberian kuesioner online dan kuesioner cetak yang disebarkan kepada siswa di kelas. Secara keseluruhan terdapat 353 data penelitian yang diperoleh, 221 data dari pengadministrasian kuesiner cetak dan 132 kuesioner online. Akan tetapi, tidak seluruh data dapat digunakan dalam penelitian ini karena banyak item yang tidak diisi secara lengkap. Oleh karena itu, data penelitian yang dapat diolah hanya 259 partisipan, dimana jumlah tersebut masih memadai untuk dilakukan analisis statistik lebih lanjut. Data demografis partisipan penelitian menunjukkan bahwa sebagian besar partisipan adalah siswi $(65,3 \%)$ dengan ratarata usia 16,76 tahun $(S D=0,62)$. Sebanyak $58,3 \%$ partisipan bersekolah di Jakarta, $18,5 \%$ di Bogor, 18,9\% di Bekasi, 2,7\% di Tangerang dan 1,5\% di Depok.

Pengambilan data penelitian ini dilakukan dengan menggunakan tiga skala, yaitu:

a. Career Decision Scale (CDS)

Alat ukur CDS dikembangkan oleh Osipow dkk. (dalam Dharma, 2017). Alat ukur ini dapat memberikan gambaran mengenai tingkat kebimbangan karier seseorang. Alat ukur ini terdiri dari 2 item favorable yang mengukur career decidedness dan 16 item favorable yang mengukur career indecision. Dalam penelitian ini, hanya digunakan 16 item yang mengukur kebimbangan karier. Itemitem tersebut akan diberikan skor berdasarkan skala Likert dengan 4 pilihan, mulai dari $1=$ sangat tidak menggambarkan diri saya, hingga $4=$ sangat menggambarkan diri saya. Salah satu item dari alat ukur CDS adalah "Saya tidak dapat membuat keputusan karier saat ini karena saya tidak tahu apa saja kemampuan saya".

b. Big Five Inventory (BFI)

Alat ukur BFI yang digunakan merupakan alat ukur kepribadian yang terdiri atas 44 item dan telah diadaptasi oleh Ramdhani (2012). Alat ukur ini digunakan untuk mengetahui kecenderungan karakteristik kepribadian partisipan yang terdiri atas dimensi openness to experiences, conscientiousness, extraversion, agreeableness, dan neuroticism. Contoh item "mengerjakan pekerjaan hingga tuntas". Partisipan diminta untuk merespon pernyataan dalam 7-poin skala Likert (1 
$=$ sangat tidak setuju sampai dengan $7=$ sangat setuju).

c. Career Decision Making Self EfficacySocial Affirmation (CDMSE-Saf)

Alat ukur Career Decision Making Self Efficacy-Social Affirmation (CDMSE Saf) yang sudah dikembangkan oleh (Arlinkasari dkk., 2016) untuk populasi dewasa muda Indonesia, berdsarkan alat ukur dari Betz dan Klein (dalam Arlinkasari dkk., 2016). Alat ukur ini terdiri atas 23 item yang mewakili 6 dimensi (accurate self-appraisal, gathering occupational information, goal selection, making plans for the future, problem solving, dan social affirmation). Validitas alat ukur diuji dengan analisis faktor yang menunjukkan nilai $K M O=$ $0,862(p<0,001)$. Seluruh item merupakan item favorable dengan respon jawaban dari sangat tidak setuju hingga sangat setuju (1 - 4 skala Likert). Contoh item yang termasuk dalam alat ukur CDMSE-Saf adalah "Memilih bidang karier yang sesuai dengan gaya hidup yang saya inginkan".

Uji hipotesis penelitian dilakukan dengan menggunakan analisa statistik uji regresi bertingkat (hierarchical regression) untuk mengetahui besarnya peranan masing- masing faktor terhadap kebimbangan karier pada siswa SMA kelas XII. Selain itu, penelitian ini juga ingin mengetahui apakah dengan adanya penambahan variabel keyakinan dalam pengambilan keputusan karier dapat lebih menjelaskan peranan faktor-faktor yang mempengaruhi kebimbangan karier pada siswa SMA kelas XII (Kim, 2016). Pemilihan uji hipotesa tersebut berdasarkan pada hasil penelitian sebelumnya menunjukkan bahwa faktor kepribadian sudah cukup konsisten dalam memprediksi kebimbangan karier, sementara peranan keyakinan dalam pengambilan keputusan karier terhadap kebimbangan karier masih menunjukkan hasil yang tidak konsisten.

\section{HASIL DAN PEMBAHASAN}

Hasil uji korelasi menunjukkan bahwa faktor kepribadian neuroticism berkorelasi positif dengan kebimbangan karier. Sementara itu, faktor kepribadian openness to experience dan conscientiousness serta keyakinan dalam pengambilan keputusan karier berkorelasi negatif dengan kebimbangan karier. Faktor kepribadian agreeableness dan extraversion tidak berkorelasi dengan kebimbangan karier. Hasil uji korelasi dapat dilihat pada Tabel 1.

Tabel 1.

Koefisien Alpha Cronbach, Mean, Standar Deviasi dan Korelasi Antar Variabel, N = 259

\begin{tabular}{lccccccccccc}
\hline Dimensi dan Variabel & $\alpha$ & Mean & $S D$ & 1 & 2 & 3 & 4 & 5 & 6 & 7 \\
\hline Career Indecision (1) & 0,839 & 41,83 & 6,73 & - & & & & & \\
Openness to experience (2) & 0,815 & 38,27 & 6,28 & $-0,225^{*}$ & - & & & & \\
Conscientiousness (3) & 0,748 & 32,84 & 5,55 & $-0,139^{*}$ & $0,403^{*}$ & - & & & \\
Extraversion (4) & 0,832 & 30,52 & 7,72 & $-0,043$ & $0,258^{*}$ & $0,312^{*}$ & - & & \\
Agreeableness (5) & 0,627 & 31,10 & 4,89 & $-0,090$ & $0,198^{*}$ & $0,358^{*}$ & $0,211^{*}$ & - & \\
Neuroticism (6) & 0,715 & 29,25 & 5,22 & $0,167^{*}$ & $-0,165^{*}$ & $-0,045$ & $-0,206^{*}$ & $-0,065$ & - \\
Career Decision Making & 0,847 & 73,29 & 8,68 & $-0,178^{*}$ & $0,306^{*}$ & $0,318^{*}$ & $0,221^{*}$ & $0,202^{*}$ & $-0,146^{*}$ & -
\end{tabular}

Self-Efficacy (7)

Keterangan: ${ }^{*} p<0,05$

Penelitian ini bertujuan untuk mengetahui peranan faktor kepribadian dan keyakinan dalam pengambilan keputusan karier terhadap kebimbangan karier siswa SMA kelas XII. Berdasarkan hasil uji regresi bertingkat (lihat Tabel 2), diketahui bahwa pada model 1 variabel kepribadian berperan sebesar $\quad 7,5 \% \quad\left(\Delta R^{2}=0,075 ; \quad F_{\Delta R^{2}}=4,088\right.$; $p=0,01$ terhadap kebimbangan karier siswa SMA kelas XII. Hasil ini menunjukkan bahwa faktor kepribadian berperan kecil terhadap kebimbangan karier siswa. 
Meskipun demikian, di antara faktor kepribadian diketahui bahwa hanya openness to experience $(\beta=-0,197 ; p=0,007)$ dan neuroticism $(\beta=0,186 ; p=0,022)$ yang berperan signifikan terhadap kebimbangan karier. Hasil ini menunjukkan bahwa karakteristik kepribadian individu yang cenderung terbuka terhadap hal baru, membantu siswa dalam mengurangi kebimbangan karier yang dihadapi. Sementara itu, siswa yang memiliki karakteristik neuroticism yang tinggi cenderung akan mengalami kebimbangan karier.

Tabel 2.

Hasil Uji Regresi Bertingkat

\begin{tabular}{lcccc}
\hline \multirow{2}{*}{ Variabel } & \multicolumn{2}{c}{ Model 1 } & \multicolumn{2}{c}{ Model 2 } \\
\cline { 2 - 5 } & $B$ & $P$ & $\beta$ & $p$ \\
\hline Openness to experience & $\mathbf{- 0 , 1 9 7 *}$ & $\mathbf{0 , 0 0 7}$ & $\mathbf{- 0 , 1 7 7 *}$ & $\mathbf{0 , 0 1 7}$ \\
Conscientiousness & $-0,079$ & 0,359 & $-0,055$ & 0,527 \\
Extraversion & 0,054 & 0,351 & 0,061 & 0,288 \\
Agreeableness & $-0,046$ & 0,605 & $-0,036$ & 0,692 \\
Neuroticism & $\mathbf{0 , 1 8 6 *}$ & $\mathbf{0 , 0 2 2}$ & $\mathbf{0 , 1 7 4 *}$ & $\mathbf{0 , 0 3 1}$ \\
Career Decision Making Self-Efficacy & & & $-0,081$ & 0,115 \\
& & & & 0,084 \\
$\mathrm{R}^{2}$ & 0,075 & & 0,009 & \\
$\Delta \mathrm{R}^{2}$ & 0,075 & & 2,502 & \\
$\mathrm{~F}_{\Delta \mathrm{R}}{ }^{2}$ & 4,088 & & & \\
\hline
\end{tabular}

Hasil penelitian Page, Bruch, dan Haase (2008) menunjukkan bahwa empat faktor kepribadian yaitu neuroticism, extraversion, openness, dan conscientiousness berperan terhadap kebimbangan karier, dengan peranan paling besar disebabkan oleh faktor kepribadian neuroticism. Penelitian lainnya yang dilakukan oleh Utami, Grasiaswaty, dan Akmal (2018) menemukan bahwa hanya dimensi conscientiousness berkorelasi negatif dengan kebimbangan karier dan neuroticism berkorelasi positif dengan kebimbangan karier. Sementara itu, Lounsbury dkk. (2005) menunjukkan bahwa karakteristik kepribadian agreeableness dan conscientiousness berkaitan positif dengan kemampuan seseorang dalam pengambilan keputusan karier, sedangkan karakteristik kepribadian neuroticism menyebabkan seseorang sulit dalam mengambil keputusan karier. Beberapa hasil penelitian tersebut cukup konsisten menunjukkan bahwa karakteristik kepribadian neuroticism berperan dalam meningkatkan kebimbangan karier individu.
Hasil penelitian ini juga menunjukkan bahwa faktor kerpibadian neuroticism berperan dalam memprediksi kebimbangan karier pada siswa SMA kelas XII. Hasil metaanalisis yang dilakukan oleh Martincin dan Stead (2015) menunjukkan bahwa faktor kepribadian neuroticism paling berperan terhadap kesulitan invidividu dalam pengambilan keputusan karier. Individu dengan kecenderungan neuroticism tinggi digambarkan sebagai seorang yang penuh kecemasan, memiliki emosi yang tidak stabil, depresif dan kurang dapat mengontrol dorongan-dorongan yang ada dalam dirinya (Ramdhani, 2012). Karakteristik tersebut dapat mempengaruhi kemampuan seseorang dalam mengambil keputusan dalam kehidupan sehari-hari, tidak hanya spesifik pada pengambilan keputusan karier (Kelly \& Pulver, 2003). Adanya kecenderungan untuk selalu merasa cemas dan mudah mengalami stres menyebabkan seseorang dengan karakteristik kepribadian neurotic kurang yakin dengan kemampuannya dalam mengambil keputusan (Page dkk., 2008). 
Selain itu, adanya ketakutan untuk melakukan kesalahan dan menerima umpan balik negatif dari orang lain juga menyebabkan individu yang memiliki karakteristik kepribadian neurotic sulit dalam mengambil keputusan karier (Page dkk., 2008). Pada siswa SMA kelas XII, pengambilan keputusan karier terutama pemilihan jurusan merupakan salah satu tugas perkembangan yang perlu mereka persiapkan dengan baik. Kesalahan dalam pemilihan jurusan mungkin akan berdampak jangka panjang terhadap masa depan mereka. Oleh karena itu, merupakan hal yang wajar jika semakin siswa SMA kelas XII merasa cemas dan takut dalam mengambil keputusan maka akan semakin tinggi kebimbangan karier yang dirasakan.

Hasil penelitian ini juga menunjukkan bahwa faktor kepribadian openness to experience juga berperan dalam memprediksi menurunkan kebimbangan karier pada siswa. Hasil ini sejalan dengan penelitian Page dkk. (2008) yang menunjukkan bahwa terdapat hubungan positif antara karakteristik kepribadian openness dengan keyakinan pengambilan keputusan karier. Individu yang dominan pada dimensi openness to experience menunjukkan karakteristik terbuka terhadap informasi baru yang ada di lingkungan dan memiliki rasa ingin tahu yang besar (Ramdhani, 2012). Karakteristik kepribadian tersebut akan membantu seseorang dalam mencari informasi terkait dengan pilihan karier yang diminati, sehingga dapat menurunkan kebimbangan saat mengambil keputusan karier. Tidak hanya membantu dalam proses pengambilan keputusan karier, keterbukaan terhadap informasi dan pengalaman baru juga dapat membantu individu dalam menyesuaikan diri ketika sudah menjalani pilihan kariernya kelak (Jiang, 2016; Li dkk., 2015; Rudolph, Lavigne, \& Zacher, 2017)

Hasil metaanalisis yang dilakukan oleh Martincin dan Stead (2015) menunjukkan bahwa faktor kepribadian openness dan extraversion paling tidak berkaitan dengan kemampuan seseorang dalam mengambil keputusan karier. Individu dengan karakteristik openness cenderung memiliki minat yang beragam dan membutuhkan waktu lebih lama dalam mengambil keputusan (Martincin \& Stead, 2015). Akan tetapi, individu dengan karakteristik kepribadian openness juga merasakan kepuasan tersendiri ketika mencari tau banyak hal yang sesuai dengan minatnya (Page dkk., 2008) sehingga mereka semakin yakin dengan jurusan yang akan diambil. Oleh karena itu, peranan negatif faktor kepribadian openness terhadap kebimbangan karier pada siswa SMA kelas XII mungkin saja dipengaruhi oleh minat siswa. Umumnya, siswa SMA kelas XII sudah memiliki minat yang lebih terarah sesuai dengan jurusan mereka di SMA. Penelitian ini tidak melakukan pengukuran terhadap variabel minat sehingga tidak dapat membuktikan asumsi tersebut. Hal ini dapat dipertimbangkan untuk pengembangan penelitian selanjutnya.

Variabel-variabel prediktor pada model 2 memiliki peranan sebesar $8,4 \%$ terhadap kebimbang karier pada siswa SMA kelas XII, dengan peningkatan sebesar $0,9 \%$ dari model $1\left(\Delta R^{2}=0,009 ; F_{\Delta R}^{2}=2,502 ; p=0,115\right)$. Hal ini menunjukkan bahwa faktor-faktor yang sudah diuji dalam penelitian ini berperan signifikan dalam menentukan kebimbangan karier siswa. Akan tetapi, adanya penambahan variabel keyakinan dalam pengambilan keputusan karier tidak berperan terhadap kebimbangan karier siswa.

Sementara itu, jika dianalisa tanpa melibatkan variabel kepribadian hasil penelitian menunjukkan bahwa semakin tinggi keyakinan siswa dalam pengambilan kaputusan karier, maka akan semakin rendah kebimbangan karier yang dialami $(r=-0,178$; $p=0,02)$. Penelitian yang telah dilakukan oleh Dharma (2017) pada populasi mahasiswa tingkat akhir juga menunjukkan adanya hubungan negaif antara kedua variabel. Meskipun menunjukkan korelasi yang signifikan, namun keyakinan dalam 
pengambilan keputusan karier tersebut bukan menjadi salah satu prediktor dalam mempengaruhi kebimbangan karier siswa.

Hasil penelitian ini berbeda dengan hasil penelitian sebelumnya yang dilakukan oleh Guay dkk. (2003) yang menunjukkan bahwa keyakinan dalam pengambilan keputusan karier merupakan prediktor kuat terhadap kebimbangan karier pada siswa. Akan tetapi, hasil penelitian ini sejalan dengan hasil penelitian Creed dkk. (2006) yang menunjukkan bahwa perubahan pada keyakinan dalam pengambilan keputusan karier tidak menyebabkan perubahan pada kebimbangan karier pada siswa SMA. Hal ini diperkirakan bahwa keyakinan dalam pengambilan keputusan karier tidak dapat secara langsung memprediksi kebimbangan karier siswa, namun hubungan antara kedua variabel tersebut perlu dimediasi oleh variabel lain (Creed dkk., 2006). Dalam pembahasannya, Creed dkk. (2006) menyarankan untuk melibatkan variabelvariabel lain yang termasuk dalam Social Cognitive Career Theory (SCCT) seperti outcome expectation dan goal orientation.

Dalam konteks budaya Indonesia, peranan variabel keyakinan dalam pengambilan keputusan karier terhadap kebimbangan karier diperkirakan dapat dipengaruhi oleh faktor eksternal seperti dukungan dari lingkungan sekitar. Dalam kerangka teori SCCT, faktor eksternal tersebut termasuk dalam variabel dukungan dan hambatan kontekstual. Penelitian yang telah dilakukan oleh Pratiwi dan Akmal (2018) menunjukkan bahwa dukungan kontekstual berperan signifikan terhadap penurunan kebimbangan karier pada mahasiswa tingkat akhir. Keyakinan siswa kelas XII dalam pengambilan keputusan karier akan dapat menurunkan kebimbangan karier yang dialami oleh siswa, terutama jika mendapatkan dukungan dari lingkungan sekitarnya seperti dari teman, orang tua, ataupun instansi pendidikan. Penelitian lain menunjukkan bahwa meskipun sudah mendapatkan pelatihan perencanaan karier, dukungan dari lingkungan masih dibutuhkan untuk dapat meningkatkan keyakinan mahasiswa dalam mengambil keputusan karier (Baig, 2012). Dukungan sosial dan self esteem juga menunjang kemampuan individu dalam menyesuaikan diri dengan tugas perkembangan karier (Ataç, Dirik, \& Tetik, 2018). Oleh karena itu, penelitian selanjutnya juga dapat dikembangkan dengan melibatkan peranan faktor eksternal dari individu terhadap kebimbangan karier.

Pengambilan keputusan karier dan kebimbangan karier menjadi hal yang penting untuk dipelajari pada individu yang berada pada masa transisi, seperti siswa SMA tingkat akhir dan mahasiswa baru (transisi pendidikan dari sekolah menengah ke perguruan tinggi) ataupun mahasiswa tingkat akhir dan lulusan sarjana (transisi dari dunia pendidikan ke dunia kerja). Perkembangan teori karier saat ini tidak lagi menekankan pada penyelesaian tugas yang sesuai dengan tahapan karier individu, akan tetapi fokus pada kemampuan individu dalam menyesuiakan diri dalam setiap proses karier mereka yang dikenal dengan istilah adaptabilitas karier (Johnston, 2016; Rudolph dkk, 2017).

Adaptabilitas karier merupakan pengembangan dari Career Construction Theory yang dikemukakan oleh Savickas. Konstruk ini semakin berkembang setelah beberapa peneliti melakukan adaptasi dari alat ukur Career Adapt Ability Scale (CAAS) di berbagai negara di dunia pada tahun 2012 (Rudolph dkk., 2017). Di Indonesia, upaya pengembangan telah dilakukan oleh Sulistiani, Suminar, \& Hendriani (2018). Sementara itu, Ambiel, Carvalho, Martins, \& Tofoli (2016) melakukan validasi alat ukur CAAS pada populasi pekerja dan siswa di Brazil. Berdasarkan hasil penelitian tersebut, diketahui bahwa CAAS valid untuk digunakan pada kedua populasi tersebut (Ambiel dkk., 2016). Işık dkk., (2018) juga melakukan validasi alat ukur CAAS pada tiga kelompok usia berbeda (siswa, mahasiswa dan pekerja) yang juga 
menunjukkan bahwa alat ukur tersebut valid dan reliabel untuk mengukur adaptabilitas karier semua kelompok usia. Oleh karena itu, adaptabilitas karier dapat diteliti pada pekerja maupun pelajar.

Penelitian mengenai adaptabilitas karier pada siswa SMA kelas XII mulai banyak dilakukan (Sulistiani \& Handoyo, 2018). Beberapa contoh penelitian yang pernah dilakukan mengenai adaptabilitas karier pada siswa seperti: hubungan aspirasi karier dan adaptabiltias karier (Hirschi, 2010), peran dukungan sosial terhadap kemampuan beradaptasi pada siswa SMA yang langsung memasuki dunia kerja (Han \& Rojewski, 2015), peran persepsi terhadap hambatan yang dialami terhadap adaptabilitas karier (Urbanaviciute, Pociute, Kairys, \& Liniauskaite, 2016), kebermaknaan hidup dan adaptabilitas karier pada siswa SMA (Yuen \& Yau, 2015). Duffy, Douglass, \& Autin (2015) melakukan penelitian mengenai adaptabilitas karier dan kepuasan akademik dengan keyakinan dalam pengambilan keputusan karier sebagai variabel moderator. Hasil penelitiannya menunjukkan bahwa adaptabilitas karier merupakan prediktor penting dalam meningkatkan keyakinan dalam pengambilan keputusan karier dan kepuasan akademik siswa

Penelitian terdahulu mengenai adaptabilitas karier umumnya dilakukan pada siswa SMA secara umum, baik yang mengalami kebimbangan karier maupun mereka yang sudah yakin dengan keputusan kariernya. Pengembangan penelitian berikutnya menjadi menarik jika dilakukan untuk mengetahui adaptabilitas karier pada siswa yang mengalami kebimbangan karier, serta mengaitkannya dengan variabel lain yang menjadi indikator keberhasilan adaptabilitas karier, seperti kepuasan akademik, prestasi akademik, dan sebagainya pada populasi siswa yang mengalami kebimbangan karier. Agar mendapatkan gambaran mengenai proses perubahan tersebut, pengembangan penelitian berikutnya dapat dilakukan dengan menggunakan metode longitudinal (me- lakukan lebih dari satu kali pengukuran) seperti yang telah dilakukan oleh Rogers dan Creed (2011) pada populasi siswa SMA kelas XII dengan jeda pengambilan data minimal 6 bulan dan Praskova, Hood, dan Creed (2014) yang melakukan dua kali pengambilan data dengan jeda 6 bulan pada populasi dewasa muda.

\section{SIMPULAN}

Hasil penelitian menunjukkan bahwa karakteristik kepribadian neuroticism berperan positif dalam memprediksi kebimbangan karier pada siswa SMA kelas XII, sedangkan faktor kepribadian openness to experience berperan dalam memprediksi penurunan kebimbangan karier siswa SMA kelas XII. Sementara itu, faktor kepribadian lainnya seperti conscientiousness, agreeableness, extraversion dan keyakinan siswa dalam pengambilan keputusan karier tidak berperan dalam memprediksi kebimbangan karier siswa. Oleh karena itu, intervensi yang dapat diberikan untuk mengatasi masalah kebimbangan karier siswa adalah dengan mengurangi kecemasan dan ketakutan dalam pengambilan keputusan karier dan mendorong siswa untuk lebih mencari tau informasi mengenai karier yang ingin ditekuninnya.

Penelitian selanjutnya yang ingin mengetahui peranan faktor kebribadian terhadap kebimbangan karier dapat melibatkan variabel minat dan kesesuaian minat siswa. Penelitian yang ingin mengetahui peranan keyakinan dalam pengambilan keputusan karier terhadap kebimbangan karier siswa dapat melakukan pengembangan penelitian dengan melibatkan variabel lain seperti outcome expectation, goal orientation, dan contextual factor yang ada dalam social cognitive career theory. Selain itu, pengembangan penelitian juga dapat dilakukan dengan melihat adaptabilitas karier pada populasi siswa yang mengalami kebimbangan karier dan menggunakan lebih dari satu kali pengukuran untuk mengetahui 
proses perubahan kebimbangan karier yang dialami.

\section{UCAPAN TERIMA KASIH}

Terima kasih kepada Yayasan YARSI yang sudah mendanai penelitian ini melalui Hibah Penelitian Internal YARSI tahun anggaran 2017/2018.

\section{DAFTAR PUSTAKA}

Ambiel, R. A. M., Carvalho, L. de F., Martins, G. H., \& Tofoli, L. (2016). Comparing the adaptabilities of Brazilian adolescent students and adult workers. Journal of Vocational Behavior, 94, 20-27. https://doi.org/10.1016/j.jvb.2016.02.00 5

Arlinkasari, F., Rahmatika, R., \& Akmal, S. Z. (2016). The Development of Career Decision Making Self-Efficacy Scale ( Indonesia Version ). In International Symposium on Business and Social Science, Jeju Island, South Korea (pp. 148-158). Retrieved from https://www.researchgate.net/publicatio n/320755521_The_Development_of_Ca reer_Decision_Making_Self-

Efficacy_Scale_Indonesia_Version

Ataç, L. O., Dirik, D., \& Tetik, H. T. (2018). Predicting career adaptability through self-esteem and social support: A research on young adults. International Journal for Educational and Vocational Guidance, 18(1), 45-61. https://doi.org/10.1007/s10775-0179346-1

Baig, S. T. (2012). The Effects of a Career Development Course on Career and College Major Decision-Making in College Students. The University of Montana.

Betz, N. E., \& Hackett, G. (2006). Career self-efficacy theory: Back to the future.
Journal of Career Assessment, 14(1), 311.

https://doi.org/10.1177/1069072705281 347

Creed, P. A., \& Patton, W. (2001). Developmental Issues of Career Maturity and Decision Status. The Career Development Quarterly, 49(June), 336-351.

Creed, P., Patton, W., \& Prideaux, L. A. (2006). Causal relationship between career indecision and career decisionmaking self-efficacy: A longitudinal cross-lagged analysis. Journal of Career Development, 33(1), 47-65. https://doi.org/10.1177/0894845306289 535

Dharma, G. (2017). Hubungan Antara Keyakinan Dalam Pengambilan Keputusan Karier dengan Kebimbangan Karier pada Mahasiswa Tingkat Akhir serta Tinjauannya Menurut Islam. Skripsi Universitas YARSI.

Duffy, R. D., Douglass, R. P., \& Autin, K. L. (2015). Career adaptability and academic satisfaction: Examining work volition and self efficacy as mediators. Journal of Vocational Behavior, 90, 4654.

https://doi.org/10.1016/j.jvb.2015.07.00 7

Guay, F., Senécal, C., Gauthier, L., \& Fernet, C. (2003). Predicting career indecision: A self-determination theory perspective. Journal of Counseling Psychology, 50(2), 165-177. https://doi.org/10.1037/0022-

0167.50.2.165

Han, H., \& Rojewski, J. W. (2015). GenderSpecific Models of Work-Bound Korean Adolescents' Social Supports and Career Adaptability on Subsequent Job Satisfaction. Journal of Career Development, 42(2), 149-164. 
https://doi.org/10.1177/0894845314545 786

Hirschi, A. (2010). Swiss Adolescents' Career Aspirations: Influence of Context, Age, and Career Adaptability. Journal of Career Development, 36(3), 228-245. https://doi.org/10.1177/0894845309345 844

Iş1k, E., Yeğin, F., Koyuncu, S., Eser, A., Çömlekciler, F., \& Yıldırım, K. (2018). Validation of the Career Adapt-Abilities Scale-Short Form across different age groups in the Turkish context. International Journal for Educational and Vocational Guidance, 18(3), 297314. https://doi.org/10.1007/s10775018-9362-9

Jiang, Z. (2016). Proactive personality and career adaptability: The role of thriving at work. Journal of Vocational Behavior. https://doi.org/10.1016/j.jvb.2016.10.00 3

Johnston, C. S. (2016). A Systematic Review of the Career Adaptability Literature and Future Outlook. Journal of Career Assessment, 26(1), 3-30. https://doi.org/10.1177/1069072716679 921

Kelly, K. R., \& Pulver, C. A. (2003). Refining measurement of career indecision types: A validity study. Journal of Counseling and Development: JCD, 81(4), 445-454. https://doi.org/10.1002/j.15566678.2003.tb00271.x

Kementrian Pendidikan dan Kebudayaan. (2017). Statistik Sekolah Menengah Atas (SMA) 2016/2017. Jakarta. Retrieved from http://publikasi.data.kemdikbud.go.id/u ploadDir/isi_C4BEF388-2A03-4B749C02-E976CE8177D6_.pdf
Kim, B. (2016). Hierarchical Linear Regression. Retrieved December 19, 2018, from https://data.library.virginia.edu/hierarch ical-linear-regression/

Li, Y., Guan, Y., Wang, F., Zhou, X., Guo, K., Jiang, P., Fang, Z. (2015). Big-five personality and BIS/BAS traits as predictors of career exploration: The mediation role of career adaptability. Journal of Vocational Behavior, 89, 3945.

https://doi.org/10.1016/j.jvb.2015.04.00 6

Lounsbury, J. W., Hutchens, T., \& Loveland, J. M. (2005). An investigation of big five personality traits and career decidedness among early and middle adolescents. Journal of Career Assessment, 13(1), 25-39. https://doi.org/10.1177/1069072704270 272

Martincin, K. M., \& Stead, G. B. (2015). Five-Factor Model and Difficulties in Career Decision Making: A MetaAnalysis. Journal of Career Assessment, 23(1), 3-19. https://doi.org/10.1177/1069072714523 081

Napitupulu, E. L. (2018, April 27). Kualitas Pendidikan Rendah. Kompas. Retrieved from https://kompas.id/baca/utama/2018/04/2 7/kualitas-pendidikan-rendah/

Page, J., Bruch, M. A., \& Haase, R. F. (2008). Role of perfectionism and FiveFactor model traits in career indecision. Personality and Individual Differences, 45(8), 811-815. https://doi.org/10.1016/j.paid.2008.08.0 13

Praskova, A., Hood, M., \& Creed, P. A. (2014). Testing a calling model of 
psychological career success in Australian young adults: A longitudinal study. Journal of Vocational Behavior, $85(1)$, 125-135. https://doi.org/10.1016/j.jvb.2014.04.00 4

Pratiwi, D. I., \& Akmal, S. Z. (2018). Peran contextual support dan barrier terhadap career indecision pada mahasiswa tingkat akhir. Jurnal Ilmiah Psikologi Terapan, 06(02), 194-206.

Ramdhani, N. (2012). Adaptasi Bahasa dan Budaya Inventori Big Five. Jurnal Psikologi, 39(2), 189-207.

Rogers, M. E., \& Creed, P. A. (2011). A longitudinal examination of adolescent career planning and exploration using a social cognitive career theory framework. Journal of Adolescence, 34(1), 163-172. https://doi.org/10.1016/j.adolescence.20 09.12.010

Rudolph, C. W., Lavigne, K. N., \& Zacher, H. (2017). Career adaptability: A metaanalysis of relationships with measures of adaptivity, adapting responses, and adaptation results is. https://doi.org/10.1016/j.jvb.2016.09.00 2

Sugiyono. (2010). Metode Penelitian Kuantitatif, Kualitatif, dan $R \& D$. Bandung: Alfabeta.

Sulistiani, W., \& Handoyo, S. (2018). Career Adaptability: The Influence of Readiness and Adaptation Success in the Education Context: a Literature Review. https://doi.org/10.2991/acpch-
17.2018 .32

Sulistiani, W., Suminar, D. R., \& Hendriani, W. (2018). The Career Adapt-Abilities Scale- Indonesian Form: Psychometic. In The 4th International Conference on Education (Vol. 4, pp. 1-9). https://doi.org/10.17501/24246700.2018 .4201

Talib, M. A., \& Tan, K. A. (2009). Predictors of career indecision among malaysian undergraduate students. European Journal of Social Sciences, $8(2), \quad 215-224$. Retrieved from http://psasir.upm.edu.my/7024/1/ejss_8 _2_02.pdf

Urbanaviciute, I., Pociute, B., Kairys, A., \& Liniauskaite, A. (2016). Perceived career barriers and vocational outcomes among university undergraduates: Exploring mediation and moderation effects. Journal of Vocational Behavior, 92,

12-21. https://doi.org/10.1016/j.jvb.2015.11.00 1

Utami, S. A., Grasiaswaty, N., \& Akmal, S. Z. (2018). Hubungan Tipe Kepribadian Berdasarkan Big Five Theory Personality dengan Kebimbangan Karier pada Siswa SMA. Psikogenesis, 6(2), 11-18. https://doi.org/10.24854/jps.v6i1.629

Yuen, M., \& Yau, J. (2015). Relation of career adaptability to meaning in life and connectedness among adolescents in Hong Kong. Journal of Vocational Behavior, 91, 147-156. https://doi.org/10.1016/j.jvb.2015.10.00 3 